\title{
СУЩНОСТЬ МЕТОДИКИ ПРОДУКТИВНОГО ОБУЧЕНИЯ
}

\author{
Маракушкина Елена Викторовна \\ преподаватель английского языка \\ МОУ «Средняя общеобразовательная \\ школа № 13 им. А.А. Завитухина»
}

Аннотация: Статья посвящена методикам продуктивного обучения. Рассматривается сущность эвристического обучения, формируемые умения в соотношении с применяемыми видами деятельности, системами форм и методов эвристического обучения и технологиями, носящими интегральный и комплексный характер.

Ключевые слова: Эвристическое обучение; когнитивные, кревтивные, оргдеятельностные методы; обучение в сотрудничестве, Jigsaw, метод проектов.

\section{THE ESSENCE OF THE METHODOLOGY OF PRODUCTIVE LEARNING}

\section{Marakushkina Elena Viktorovna}

\begin{abstract}
The article is devoted to the methods of productive learning. The essence of heuristic learning, the skills formed in relation to the types of activities used, systems of forms and methods of heuristic learning and technologies of an integral and complex nature are considered.
\end{abstract}

Key words: Heuristic learning; cognitive, creative, organizational methods; collaborative learning, Jigsaw, project method.

Задачи эвристического обучения - развитие траектории ученика, включающее в себя развитие целей, технологий, содержания образования. Ученик ставит собственные цели, открывает знания, выпускает учебную продукцию, т.е. содержание образования для него оказывается вариативным и развивается в ходе деятельности ученика. Набор качеств ученика позволяет выбирать оптимальные виды технологий. Так, способность к творческой 


\section{ОБРАЗОВАТЕЛЬНЫЕ ТЕХНОЛОГИИ \\ В СОВРЕМЕННОМ УЧЕБНО-ВОСПИТАТЕЛЬНОМ ПРОСТРАНСТВЕ}

деятельности называется креативностью (воображение, самобытность, проницательность и т.д.); способность к познанию - когнитивная деятельность (любознательность, физиологические качества - умения слышать, видеть, осязать и чувствовать объект; поиск проблем, наличие личностного понимания и т.п.). Для того чтобы креативные и когнитивные процессы имели общую структурную основу и выражались в общеобразовательных результатах ученика, нужна организационная деятельность, которая осуществляется на базе таких способностей, как целеполагание, целеустремлённость, планируемость, рефлексия и др.

В ходе изучения каждой темы необходимо указывать развиваемые умения детей, приоритетные для каждой темы. Каждой развиваемой способности ставятся в соответствие виды деятельности учеников (общеучебные, предметные, оргдеятельностные), их реализация происходит на основе ряда технологий, включающих системы форм и методов [1, с. 155].

Когнитивные методы, или методы научного познания, делятся на научные (методы исследований - сравнение, аналогия, синтез, классификация и др.), методы учебных предметов и метапредметные [2, 134] Например, метод вживания опирается на эмпатию, применим для «вселения» учеников в предметы окружающего мира. Посредством чувственно-образных и мысленных представлений ученик пытается изучить предмет изнутри. Метод смыслового видения основан на смысловом вопросе: какова причина этого объекта, что у него внутри. Метод эвристического исследования - выбирается объект исследования, ученикам предлагается самостоятельно исследовать объект по плану: цели исследования, план работы, факты об объекте, опыты, новые факты, возникшие проблемы, версии ответов, гипотезы, рефлексные суждения, выводы.

Креативные методы обеспечивают ученикам возможность создания собственных образовательных продуктов. Могут быть интуитивными (пед. методы ученика в роли учителя), алгоритмическими (алгоритм как логическая основа), эвристиками («наведение на возможные решения задач и исключение неверных»).Например, метод придумывания- создания неизвестного ученикам продукта в результате творческих действий (создали новую школу с расписанием, правилами); метод синектики (Дж. Гордон) - базируется на методе раздичного вида аналогий (словесной, личностной, образной), инверсии, ассоциации. Нахождение новых, неожиданных идей путём составления 


\section{ОБРАЗОВАТЕЛЬНЫЕ ТЕХНОЛОГИИ \\ В СОВРЕМЕННОМ УЧЕБНО-ВОСПИТАТЕЛЬНОМ ПРОСТРАНСТВЕ}

различных комбинаций, известных и неизвестных элементов называется методом мерфологического ящика (Ф. Цвики).

Оргдеятельностные методы включают в себя методы ученического целеполагания, планирования, самоорганизации, рецензий, контроля и рефлексии.

Существуют комплексные технологии, включающие в себя разные виды методов. Обучение в сотрудничестве [3, с. 5] - оргдеятельностно-когнитивная технология позволяет эффективно достигать прогнозируемых результатов, обеспечивает необходимые условия для личностного развития учащегося. Идеология обучения в сотрудничестве была разработана тремя группами американских педагогов: Р. Славиным из университета Джона Хопкинса, Р. Джонсоном и Д. Джонсоном из университета штата Миннессота; группой Э. Аронсона из университета штата Калифорния. Основная идея технологии создать условия для активной совместной деятельности учащихся в разных учебных ситуациях [4]. Обучающиеся объединются в небольшие группы, им даётся одно общее задание, оговорив роль каждого ученика в его выполнении. Каждый член группы отвечает не только за результат своей работы, но и за результат группы. Поэтому слабые ученики стараются выяснить у сильных все не понятые ими вопросы, а сильные учащиеся заинтересованы в том, чтобы все члены группы досконально разобрались в материале. Условия данной технологии: группы формируются до урока с учётом совместимости детей, в каждой группе должен быть сильный, средний и слабый ученик; группе даётся одно задание, но при его овыполнении предусматривается распределение ролей; оценивается работа всей группы и каждый ученик сам оценивает результат труда; учитель выбирает учащегося группы, который должен отчитаться за задание.

Другой вариант разработал Э. Аринсон в 1978 г. и назвал его Jigsaw (в дословном переводе с английского «ажурная пила, машинная ножовка». Учащиеся организовываются в группы по 4-6 человек длятворческой работы над учебным материалом, который разделён на фрагменты (логические или смысловые блоки). Каждый член группы находит материал по своей подтеме. Затем обучающиеся, изучающие один и тот же вопрос, но работающие в разных группах,встречаются и обмениваются информацией как эксперты по данному вопросу. Затем они возвращаются в группы и обучают тому, что узнали, товарищей в группе. Те, в свою очередь, рассказывают о своей части задания. 
На заключительном этапе, который проводится фронтально, учитель может попросить любого учащегося команды ответить на любой вопрос по данной теме. Вопросы задает не только учитель, в основном это делают члены других групп. Ученики одной группы могут дополнять ответ одногруппников.

Метод проектов как частный случай интегральной технологии обучения личностно-ориентирован, использует множество дидактических подходов обучение в деле, совместное учение, мозговой штурм, ролевая игра, эвристическое и командное обучение [5, с. 38]. Проектное обучение самомотивируемо, что означает возрастание интереса и вовлечённости в работу по мере её выполнения. Цели метода ставятся в когнитивной, аффективной, психомоторной областях на всех уровнях - знания, понимания, применения, анализа, синтеза. Проектная деятельность позволяет учиться на собственном опыте, ученики видят продукт собственного труда. Стадии работы над проектом: подготовка (определение темы и целей), планирование, деятельность, результаты, представление, рефлексия, оценка.

\section{Список литературы}

1. А. В. Хуторской. Взаимодействие эвристического и нормативного компонентов образования: анализ экспериментальных данных // Воспитобразоват процесс: Устремление к идеалу: сб. Научных трудов - М.: Серпухов, 1996- c. $154-158$

2. А.В.Хуторской. Развитие одарённости школьников: Методика продуктивного обучения: Пособие для учителя.- М., Гуманитар. Изд. Центр ВЛАДОС, 2000- 320c.

3. Е.С.Палат. Обучение в сотрудничестве //ИЯИЛ- 2002 -№3 - с. 4-7

4. http://info.z-pdf.ru/32pedagogika/249389-1-ideologiya-obucheniya-sotrud nichestve-bila-detalno-razrabotana-tremya-gruppami-amerikanskih-pedagogov-sla vin.php

5. Т.В.Душевина. Проектная методика на уроках иностранных языков / ИЯШ- 2003- №5 - С.38-41. 